\title{
Love's Labor's Lost? Judicial Tenure Among Federal Court Judges: $1945-2000$
}

\author{
Albert Yoon $\dagger$
}

\section{TABLE OF CONTENTS}

Introduction

I. The Legal and Legislative Debates over Judicial Compensation.... 1032

II. The Study of Judicial Tenure ..................................................... 1039

III. A Description of the Data Relating to Judicial Tenure ................... 1042

IV. Explanations of Judicial Tenure ................................................. 1043

A. Overview................................................................... 1043

B. Time-Series Trends ........................................................ I045

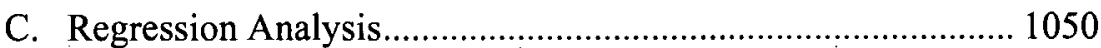

D. Wealth and Recent Appointments ...................................... I054

V. Is Compensation Affecting Tenure?.............................................. 1055

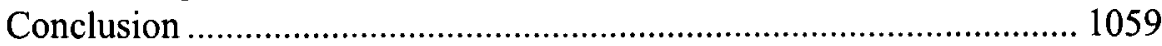

Copyright (C) 2003 California Law Review, Inc. California Law Review, Inc. (CLR) is a California nonprofit corporation. CLR and the authors are solely responsible for the content of their publications.

$\dagger$ Assistant Professor, Northwestern University School of Law, Northwestern University Department of Political Science (by courtesy). B.A., Yale University; J.D., Ph.D. (Political Science), Stanford University. I am grateful for the generous support of Northwestern University School of Law in making this research possible. A special thanks to Adam Waskowski and Brian Doughtery for their research assistance and Pegeen Bassett for her library referenee support. I am indebted to Steve Saltzgiver at the Federal Judicial Center and Sheldon Goldman for providing data. This Article benefited greatly from the comments of Richard Brooks, Tom DeLeire, Tracey George, Nancy King, Helen Levy, Tom Merrill, Richard Posner, Robert Rasmussen, Jim Speta, Robert Sitkoff, Kent Syverud, Emerson Tiller, Robert Weisberg, Christopher Yoo, and participants at the 2002 Law \& Society Conference and the 2003 Legal Theory Workshop at Vanderbilt University Law School. Any remaining errors are my own. 


\title{
Love's Labor's Lost? Judicial Tenure Among Federal Court Judges: 1945-2000
}

\author{
Albert Yoon
}

Jurists and legal scholars have long decried the diminishing real salaries of federal judges, claiming that this decline has adversely affected the willingness of federal judges to remain on the bench. Using data provided by the Administrative Office of the United States Courts, this Article analyzes the tenure trends of federal judges who retired from the bench during 1945-2000. Using time-series regression analysis, this Article shows that, contrary to these claims, tenure trends remained fairly stable over this period for both district and circuit courts. Indeed, the only observable trends were towards longer tenure. The data reveals, however, that recent judicial appointees are wealthier than their predecessors, which may reflect a possible selection effect in members of the bar willing to join the federal bench. Moreover, while judicial salaries have diminished, expenditures within the federal judiciary are growing at a geometric rate, suggesting that judges may enjoy increasing nonsalary benefits.

\section{INTRODUCTION}

"It's a privilege to do this job."

U.S. Supreme Court Justice Stephen G. Breyer, describing his experience on the bench.

"It's not the sort of situation you want. ... I went out and got a job to take care of my grandchildren."

Edward B. Davis, former Chief Judge of the Southern District of Florida, describing his experience on the bench and why he left.

For most members of the legal profession, becoming a federal judge signifies the culmination of a legal career. After years of distinguished

1. Public Hearings of the National Commission on the Public Service, A Time of Crisis and Opportunity, Brookings INST., July 15, 2002, available at http://www.brook.edu/dybdocroot/ comm/transcripts/20020715.htm [hereinafter Time of Crisis].

2. Jonathan D. Glatcr, Federal Bench Needs a Raise, Bar Groups Say in Report, N.Y. Times, Feb. 13, 2001, at A23. 
service, typically in private practice, government, or a state judgeship, occasionally an attorney is recognized by a presidential nomination for a federal judgeship, and, in most cases, Senate confirmation. A federal judgeship offers the opportunity to serve the public, directly shape the law, and develop the minds of subsequent generations of attorneys through the mentorship of judicial clerks. These benefits are accompanied by lifetime tenure and respect from the legal community. What could be the detraction?

For some members of the federal judiciary, however, most notably U.S. Supreme Court Chief Justice William H. Rehnquist, dissatisfaction is brewing and has been for some time. ${ }^{3}$ Federal judges now hear more cases annually on average than they did ten years ago, ${ }^{4}$ and their annual salaries adjusted for inflation have steadily declined over that period. Moreover, Chief Justice Rehnquist contends that this diminution in real salary is prompting federal judges to leave the bench in unprecedented rates. ${ }^{5}$ Other judges $^{6}$ and government officials ${ }^{7}$ have echoed this claim. Despite the salience of this issue for at least the last thirty years, there has been a surprising scarcity of scholarship exploring judicial tenure and, specifically, the factors that influence the length of time a federal judge serves on the bench. ${ }^{8}$

This Article seeks to accomplish two goals. First, it explores whether the beliefs of Chief Justice Rehnquist and other critics of the causal connection between federal judicial salaries and judicial departure are empirically valid. Second, and more importantly, it examines the trends in judicial service among lower federal court judges over the past half century, focusing on the factors that influence the length of a federal judge's service prior to retirement. This empirical inquiry is important, independent of the findings: if Chief Justiee Rehnquist's claims are correct, then the results may further motivate Congress and the public to accommodate the judges' request for salary increases; if the claims prove incorrect, then the

3. See infra text accompanying notes 14-18.

4. See infra p. 1034 fig. 2.

5. See Time of Crisis, supra note 1 (statement by Chief Justice Rehnquist) (comparing the relatively few departures during the 1960 s with the greater number in reccnt years).

6. See, e.g., id. (statement by Justice Breyer); Glater, supra note 2 (discussing judges who left the bench for financial reasons).

7. See, e.g., Mike Fuchs, Official Suggests Raise for Judges: A National Policy-Making Official Says the Country Will Suffer if Federal Judges Don't Get a Salary Hike, Greensboro News \& RECORD, June 30, 2002, at B1 (quoting Leonida Ralph Mecham, secrctary of the Judicial Conference of the United States, as saying, "the real cost of not granting adequate salaries to our federal judges must be calculated, not in today's dollars, but by the drain on our judiciary that will be caused by the loss of qualified, seasoned judges."); Glater, supra note 2 (citing Michael F. Armstrong, former advisor to Senator Alfonse M. D'Amato, who claimed that only lawyers who feel very financially secure will be willing to join the federal bench).

8. Cf. infra notes 36-37. 
results will at least redirect the discussion towards examining other, perhaps more subtle, factors that influence federal judicial tenure.

This Article has three main findings. First, tenure trends among the federal judiciary have held fairly constant over the past half century, notwithstanding the cyclical decline in inflation-adjusted salaries. In fact, the data show observable trends towards slightly longer tenure. Second, the net assets of judges recently appointed to the federal bench have been increasing, suggesting a possible selection effect amongst candidates for the federal judiciary. Third, the budget for the federal judiciary has grown at a geometric rate over this same period, vastly outpacing the rate of growth for judicial salaries. Each of these factors, while not necessarily resolving the debate over federal judicial tenure, provides important factual data and a framework for future academic and policy discussions.

Parts I and II of this Article provide context for the debate about judicial tenure: Part I discusses the legislative and legal histories relating to the compensation of federal judges; Part II reviews the existing scholarship on federal judicial tenure. Part III provides a brief description of the data collected from the Administrative Office of the United States Courts and other sources. Part IV reports the results, which employ time-series trends and regression analyses to examine the influence, if any, of political, professional, and personal factors on federal judges' length of service. Part V discusses possible implications of these results, both regarding the judicial selection process and potential reforms.

\section{The Legal and Legislative Debates over Judicial Compensation}

While Article III, Section I of the U.S. Constitution prohibits the nominal diminution of federal judicial salaries, it does not require Congress to provide cost-of-living adjustments. Given inflation, unadjusted salaries amount to a decline in real salaries from year to year. As shown in Figure I, real salaries ${ }^{9}$ for federal judges have steadily declined over the past thirty years. Over the past half century, federal judges (including Supreme Court Justices) have enjoyed only sporadic adjustments to their salary, from a low in 1954 to a peak in $1969 .^{10}$

9. Real salaries adjust for inflation, thereby measuring salaries in constant dollars. For example, consider an individual who earns $\$ 50,000$ in 1980 and $\$ 107,500$ in 2001 . This person experienced an apparent increase in salary of $\$ 57,500$, but no increase in real salary, sinee $\$ 50,000$ in 1980 is roughly equal in real dollars to $\$ 107,500$ in 2001 .

10. Another way to view this graph is to look at average real salaries over this period. In this regard, current real salaries for district and circuit judges- $\$ 150,000$ and $\$ 159,100$, respectively-are above their average for the past half century- $\$ 143,034$ and $\$ 156,277$, respectively. 


\section{Figure 1 \\ Federal Judicial Salaries \\ INFLATION ADJUSTED (2002 DOLLARS) ${ }^{11}$}

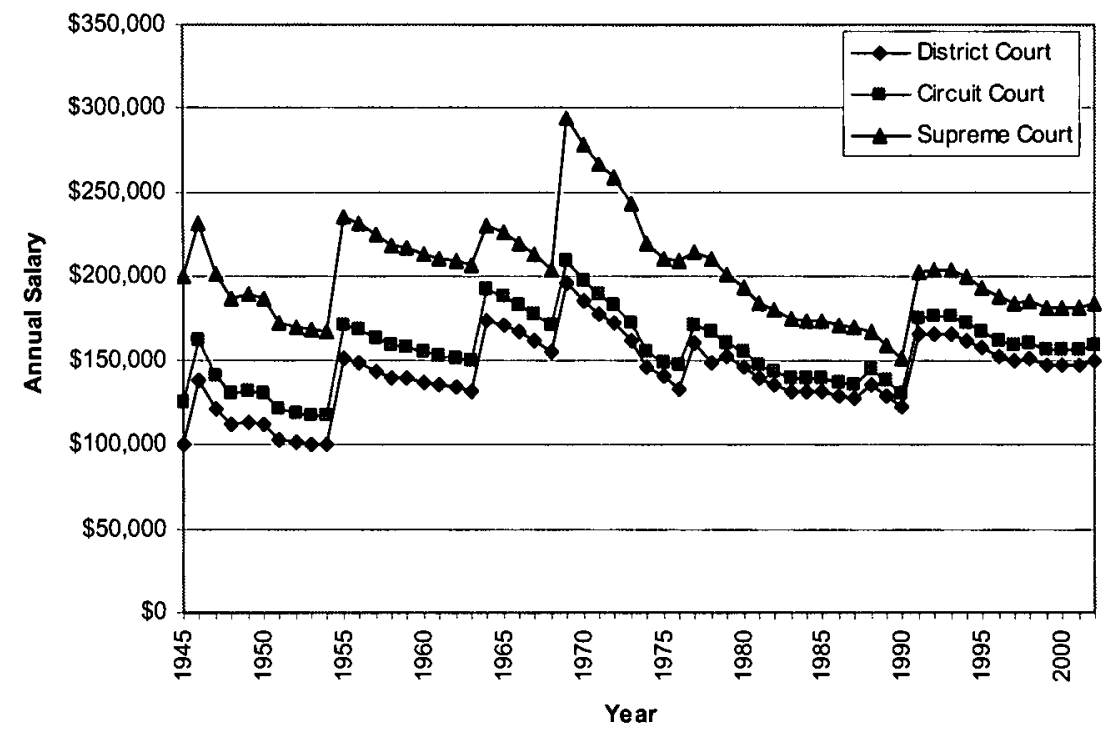

While real salaries have been relatively flat, judges' caseloads have increased over this period.

11. See Richard A. Posner, Federal Courts: Challenge and Reform 385-90 (1996) (referencing the Judiciary Aet of 1789 and subsequent judiciary acts which adjust salaries); William $\mathrm{H}$. Rehnquist, The 1996 Year-End Report on the Federal Judiciary, 29 The Third Branch 1, 2 (Jan. 1997), available at http://www.uscourts.gov/cj96.htm; William H. Rehnquist, The 1997 Year-End Report on the Federal Judiciary, 30 THE THIRD BRANCH 1, 1 (Jan. 1998), available at http://www.uscourts.gov/ttb/jan98ttb/january.htm; William H. Rehnquist, The 1998 Year-End Report on the Federal Judiciary, 31 THE THIRD BRANCH I, 3 (Jan. 1999), available at http://www.uscourts.gov/ttb/jan99ttb/january 1999.html; William H. Rehnquist, The 1999 Year-End Report on the Federal Judiciary, 32 THE THIRD BRANCH 1, 2 (Jan. 2000), available at http://www.uscourts.gov/ttb/jan00ttb/jan2000.html; William H. Rehnquist, The 2000 Year-End Report on the Federal Judiciary, 33 THE THIRD BRANCH 1, 1-4 (Jan. 2001), available at http://www.uscourts.gov/ttb/jan01 ttb/jan01.html; William H. Rehnquist, The 2001 Year-End Report on the Federal Judiciary, 34 THE THIRD BRANCH (Jan. 2002), at http://www.uscourts.gov/ $\mathrm{ttb} / \mathrm{jan} 02 \mathrm{ttb} / \mathrm{jan} 02 . \mathrm{html}$; William H. Rehnquist, The 2002 Year-End Report on the Federal Judiciary, 35 THE THIRD BRANCH (Jan. 2003), at http://www.uscourts.gov/ttb/jan03ttb/jan03.html. 
Figure 2

Federal Judicial Caseload

CASes COMmenced Per Judge ${ }^{12}$

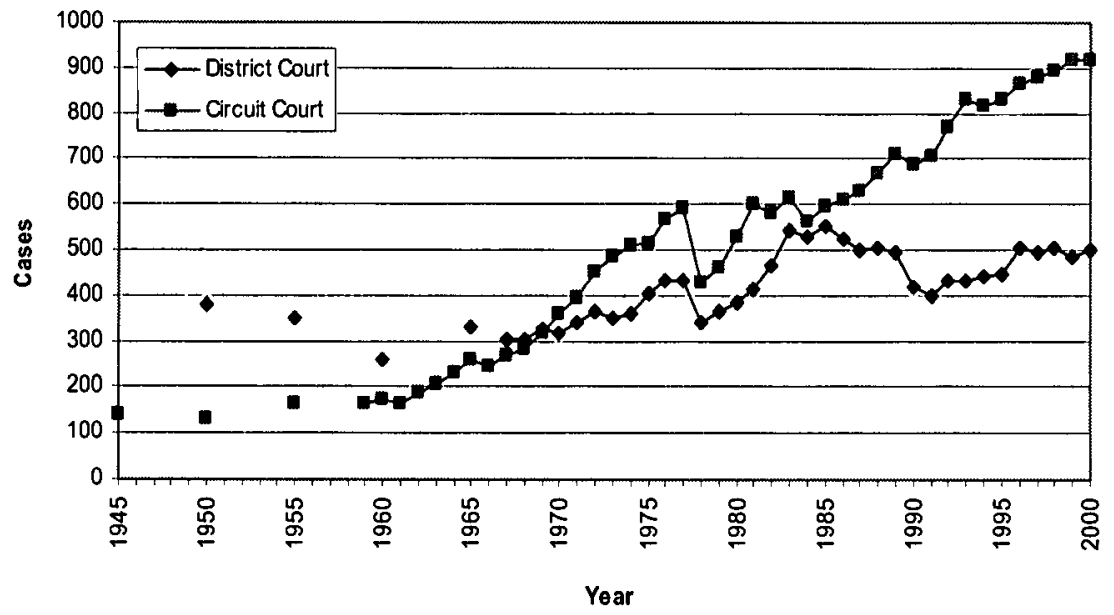

The total number of cases commenced annually has steadily increased in both the district and circuit courts over this period. As one might expect, the decreases in average caseload generally correspond to expansions of federal judgeships, which provided more judges to share in the work. The increases correspond to periods when the number of judgeships remained constant. Reading Figures 1 and 2 together, judges are hearing more cases without a corresponding increase in compensation.

While judges face largely stagnant salaries, the starting base salaries for first-year associates at large, prestigious law firms have increased and now rival the earnings of federal district and circuit judges, as illustrated in Table 1. In fact, after factoring in additional compensation like bonuses often afforded to law firm associates but not to federal judges, first-year associates may earn more than federal judges. ${ }^{13}$

12. This information was taken from past years of the U.S. Census Bureau, Statistical Abstract of the United States, which reported aggregate caseload statistics based upon the Administrative Office of the United States Courts, Annual Report of the Director from various years. The aggregate caseload for district and circuit courts is reportcd for the twelve-month period ending June 30. Data is unavailable for all years; discontinuities in the lines reflect years with unavailable data. The average caseload for district court judges was computed by dividing the total caseload across all districts by the number of authorizcd judges; the average cascload for circuit court judges was computed by dividing the total caseload across all circuits by the number of authorized judges (multiplied by three to account for three-judge panels). Because this method does not adjust for senior judges, this calculation will likely overstate the true average number of cases heard by activc judges. This method, however, is the same one used by the Bureau of Justice Statistics in computing the average judicial caseload.

13. See Insecure About Their Future: Why Some Judges Leave the Beneh, 34 THE THIRD BRANCH (Feb. 2002), at http://www.uscourts.gov/ttb/feb02ttb/feb02.html\#insecure ("lt is especially hard for federal judges to sec law clerks leave their employment after a ycar and make more than their former bosses."). 
TABLE 1

Comparison of Annual Salaries

UNADJUSTED DOLLARS ${ }^{14}$

$\begin{array}{ccccc}\text { Supreme } & \begin{array}{c}\text { Court of } \\ \text { Court }\end{array} & \begin{array}{c}\text { District } \\ \text { Court }\end{array} & \begin{array}{c}\text { 1st Year } \\ \text { Associate }\end{array} \\ 1995 & \$ 164,100 & \$ 141,700 & \$ 133,600 & \$ 70,000 \\ 1996 & \$ 164,100 & \$ 141,700 & \$ 133,600 & \$ 70,000 \\ 1997 & \$ 164,100 & \$ 141,700 & \$ 133,600 & \$ 71,502 \\ 1998 & \$ 167,900 & \$ 145,000 & \$ 136,700 & \$ 75,000 \\ 1999 & \$ 167,900 & \$ 145,000 & \$ 136,700 & \$ 85,000 \\ 2000 & \$ 173,600 & \$ 150,000 & \$ 141,300 & \$ 100,000 \\ 2001 & \$ 184,400 & \$ 153,900 & \$ 145,100 & \$ 108,750\end{array}$

Since his elevation from Associate Justice in 1986, Chief Justice Rehnquist has publicly commented on what he perceives as the inadequate compensation of federal judges, which he repeatedly has asserted is "the single greatest problem facing the judicial branch." ${ }^{15}$ Since 1997, he has raised this point in each of his Year-End Reports on the Federal Judiciary, ${ }^{16}$ and most recently spoke on this matter with Justice Breyer in July 2002 before the Volcker Commission on Public Service, in a session on "Attracting the Best and Brightest to Federal and Judicial Service."17

This trend of declining salaries, Chief Justice Rehnquist argues, carries adverse first- and second-order consequences. He contends that more judges are leaving the bench at an earlier age than ever before to pursue more lucrative options. As the problem becomes more entrenched, he argues, it will further affect the willingness of potential applicants to join the federal bench, creating a less diverse, and arguably less qualified, judiciary. ${ }^{18}$ Justice Breyer has commented that as the federal judiciary faees declining real salaries and increasing workloads, the independence and diversity of the judiciary are threatened, ultimately challenging our "basic

14. Salaries are annual and unadjusted for inflation. Judicial salaries are stated in the Federal Judiciary Act of 1789 and subsequent acts. See supra note 11. First-year associate salaries are based on a survey of U.S. law firms consisting of more than 250 attorneys provided by the National Association of Law Placement (NALP). See, e.g., National Association of Law Placement, 200I Associate Salary Survey National Summary Chart (2000-01), available at http://www.nalp.org/nalpresearch/ salindex.htm.

15. Time of Crisis, supra note 1.

16. Rehnquist, The 1997 Year-End Report on the Federal Judiciary, supra note 11, at 1; Rehnquist, The 1998 Year-End Report on the Federal Judiciary, supra note 11, at 3; Rehnquist, The 1999 Year-End Report on the Federal Judiciary, supra note 11, at 2; Rehnquist, The 2000 Year-End Report on the Federal Judiciary, supra note 11, at 1-4; Rehnquist, The 2001 Year-End Report on the Federal Judiciary, supra note 11; Rehnquist, The 2002 Year-End Report on the Federal Judiciary, supra note 11.

17. Time of Crisis, supra note 1.

18. Id. 
liberty." 19 In effect, these justices and other advocates of higher federal judicial salaries assert that declining real salaries adversely affect judicial tenure.

The debate surrounding compensation of federal judges is longstanding, dating back to at least the late 1960s. In 1967, Congress first attempted to address the issue of inadequate salaries for judges, along with the salaries of members of the legislative and executive branches, through the Federal Salary Act of $1967 .{ }^{20}$ This act created a commission, composed of private citizens appointed by the three branches, to make recommendations every four years regarding salaries within each of the three branches. ${ }^{21}$ Upon receiving these recommendations, the president would make a final reeommendation to Congress, which ultimately would decide the matter. Judges received a substantial pay increase in the first year, their highest real salary over the last one hundred years, but they saw their salaries frozen subsequently, perhaps as other policy issues gained greater salicnce. All efforts to implement an automatic cost-of-living adjustment were unsuccessful.

Following six years of frozen federal salaries, Congress in 1975 passed the Executive Salary Cost-of-Living Adjustment Act. ${ }^{22}$ As the title suggests, this act was designed to allow salaries among the three branches to keep pace with inflation. It proved more successful than the Federal Salary Act, although the Comptroller General of the United States, the administrator responsible for recommending salary increases, interpreted it such that each additional salary increase for judges required separate statutory authorization. ${ }^{23}$ As a result, on more than one occasion federal judges were denied salary increases.

Most recently, Congress passed the Ethics Reform Act of $1989,{ }^{24}$ which slightly modified both the Federal Salary Act and the Executive Salary Cost-of-Living Adjustment Act. ${ }^{25}$ Like its predecessors, the Ethics Reform Act sought to make salary adjustments systematic and less discretionary but failed to produce consistent results, as political pressure upon Congress to withhold salary adjustments prevailed. ${ }^{26}$

19. Id.

20. Pub. L. No. 90-206, $\$ 225,81$ Stat. $642-45$ (1967).

21. Id.

22. Pub. L. No. 94-82, 89 Stat. 419 (1975).

23. See 62 Comp. Gen. 54 (1982); 62 Comp. Gen. 358 (1983); 63 Comp. Gen. 141 (1983); 65 Comp. Gen. 352 (1986). For a discussion of this issue, see Am. Bar Ass'n, Federal Judicial Pay ERosion: A REPORT ON THE NEED FOR REFORM 6 (2001), available at http://www.uscourts.gov/ judicialpay.pdf.

24. Pub. L. No. 10l-194, 103 Stat. 1716 (1989).

25. The Ethics Reform Act created a Citizens' Commission on Public Service and Compensation, and also restructured the annual pay increases. $I d$.

26. See, e.g., Lawrence J. Fox, Politics Is Threatening the Federal Judiciary, Nat'L L.J., Mar. 18, 1996, at A19 (describing in part how Congress faces political pressure to not raise salaries for itself as well as the judiciary). 
In 200I, a group of federal judges challenged in court Congress's failure to raise judicial salaries in step with inflation, arguing that its failure to do so violated the Compensation Clause, Article III, Section 1 of the U.S. Constitution. ${ }^{27}$ The district court granted summary judgment in favor of the federal judgcs, holding that the Ethics Reform Act entitled judges to costof-living adjustments, which vested, for purposes of the Compensation Clause, upon its enactment. It also held that Congress's appropriations efforts to prohibit judicial salary increases did not alter its obligations under the Ethics Reform Act. ${ }^{28}$ A divided panel of the Federal Circuit, however, reversed. ${ }^{29}$ The Federal Circuit relied on the "unambiguous" holding of United States $v$. Will ${ }^{30}$ to conclude that "judicial pay increases which are enacted and effective, except in the sense that they are not yet 'due and payable' to judges, may be repealed." 31

On appeal, a divided Supreme Court denied certiorari. In dissenting from the denial of certiorari, Justice Breyer acknowledged the awkwardness of judges ruling on an issue in which they themselves would be the primary beneficiaries, but sided with the district court's holding that the Compensation Clause protects judges in circumstances where Congress has elected, as it had in the Ethics Reform Act, to guarantee to maintain federal judicial salaries. $^{32}$

Concern over political fallout has made Congress reluctant to issue themselves and federal judges pay raises commensurate with those observed in other professions. Figure 3 provides a comparison of salaries of federal judges with other professions.

27. The Compensation Clause states, in part, that judges "shall, at stated Times, receive for their services, a Compensation, which shall not be diminished during their Continuance in Office." U.S. ConsT. art. III, §1.

28. Williams v. United States, 48 F. Supp. 2d 52 (D.D.C. 1999).

29. Williams v. United States, 240 F.3d 1019 (Fed. Cir. 2001).

30. 449 U.S. 200 (1980).

31. Williams, $240 \mathrm{~F} .3 \mathrm{~d}$ at 1032 (emphasis in original).

32. Williams v. United States, 122 S.Ct. 1221 (2002) (mem.) (Breyer, J., dissenting). 
Figure 3

Comparison of Annual Salaries Across Job Sectors UNADJUSTED DOLLARs ${ }^{33}$

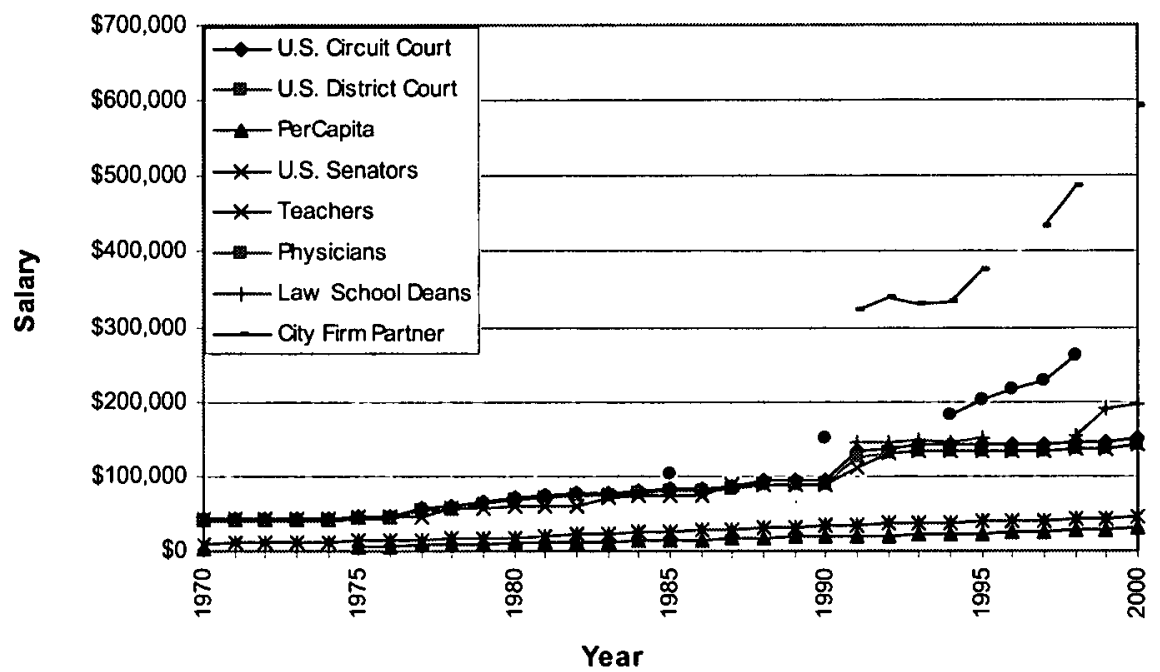

Not surprisingly, the salaries for federal judges and U.S. Senators are closely aligned, increasing in unadjusted salary from roughly $\$ 40,000$ in 1970 to roughly $\$ 150,000$ in 2000 . They were, until recent years, also closely aligned with deanships at public law schools. Conclusions regarding the trend of federal judicial salaries depend on the comparison group. Judges' salary increases compare unfavorably to those of physicians and partners at large city law firms. Conversely, judges' salary increases have greatly outpaced those of public school teachers and the per capita income over the same period. Hence the public-perception dilemma facing Congress and federal judges: their salaries exeeed those of many, if not most, professions. Of course, as Chief Justice Rehnquist has pointed out, most

33. The Administrative Office of the United States Courts provided salaries for judges. See supra note 11. The Department of Education provided information on teacher salaries. NAT'L CTR. For Educ. Statistics, U.S. Dep't of Educ., Digest of Education Statistics, 2001 tbl.81 (2001), available at http://nces.ed.gov//pubs2002/digest2001/tables/dt081.asp. The U.S. Census Bureau provided information on physician salaries and per capita salaries. U.S. Census BUREAU, STATISTICAL ABSTRACT OF THE UNITED STATES, 200I tbls.157, 647 (2001). Law school dean salaries are based on the salary of the dean of School of Law, University of California, Berkeley (Boalt Hall) from the National Law Journal. City law firm partner salaries are based on the Associate and Partner Salary Survey of large city firms from Chicago, New York, and Houston, compiled by the National Law Journal and provided by Judith Collins at the National Association for Law Placement. Data is unavailable for all years for all professions; discontinuities in the lines reflect unreported years. 
judges' occupational alternatives bear greater similarity to law firm partners than to school teachers. ${ }^{34}$

Given the history and recent closely divided case law regarding judicial compensation, the relative scarcity of scholarship on this issue, or on federal judicial tenure more generally, is surprising. Political scientists have written on turnover in Congress ${ }^{35}$ and the U.S. Supreme Court, ${ }^{36}$ but have only recently focused their attention on lower federal courts. ${ }^{37}$ The last traditional legal scholarship on the subject was written over twentyfive years ago. ${ }^{38}$ This Article extends the existing social science and legal scholarship by including recent data on federal judges and also by applying different statistical analyses to the data.

\section{II}

\section{The Study of Judicial Tenure}

The study of judicial tenure is still relatively new. The earliest studies were mostly descriptive and focused on the Supreme Court. ${ }^{39}$ Two articles of note, however, directly examined judicial salaries and tenure. Keith Rosenn argued in his 1976 article that "[b]y failing to maintain the real economic value of judicial salaries, Congress has breached the moral duty which the compensation clause of article III, section 1, imposes upon it." Providing ample data demonstrating judges' lost real income over time, Rosenn advocated a legislative remedy that would index salaries to keep pace with the rate of inflation, a measure he deemed necessary to avoid "the cost and embarrassment of the cyclical demoralization of the

34. Time of Crisis, supra note 1 (statement of Chief Justice Rehnquist) ("[I]t is not fair to compare judges' salaries to salaries in other occupations. Those lawyers who are most qualified to serve as federal judges havc opportunities to earn far more in private law practicc or business than as judges.").

35. See, e.g., Michael K. Moore \& John R. Hibbing, Situational Dissatisfaction in Congress: Explaining Voluntary Departures, $60 \mathrm{~J}$. PoL. 1088 (1998) (eoncluding that congressional tumover is largely explained by legislators' sense of their inability to achieve their stated goals).

36. See, e.g., Timothy M. Haglc, Strategic Retirements: A Political Model of Turnover on the United States Supreme Court, 15 PoL. Behav. 25 (1993); Gary King, Presidential Appointments to the Supreme Court: Adding Systematic Explanation to Probabilistic Description, 15 AMER. POL. Q. 373, 377-86 (1987); Peverill Squire, Politics and Personal Factors in Retirement from the United States Supreme Court, 10 PoL. BeHAv. I80 (1988).

37. See, e.g., Deborah J. Barrow \& Gary Zuk, An Institutional Analysis of Turnover in the Lower Federal Courts, 1900-1987, 52 J. PoL. 457 (1990); James F. Spriggs II \& Paul J. Wahlbeck, Calling It Quits: Strategic Retirement on the Federal Courts of Appeals, 1893-199I, 48 PoL. RES. Q. 573 (1995).

38. See Keith S. Rosenn, The Constitutional Guaranty Against Diminution of Judicial Compensation, 24 UCLA L. REv. 308 (1976); Robert A. Sprecher, The Threat to Judicial Independence, 5 I IND. L.J. 380 (1976) (arguing that inadequate judicial compensation has become a crisis).

39. See, e.g., David J. Danelski, A Supreme Court Justice Steps Down, 54 Y ALE L.J. 41 I (1965); John R. Schmidhauser, When and Why Justices Leave the Supreme Court, in Politics of AgE 117-34 (Wilma Donahue \& Clark Tibbitts eds., 1962).

40. Rosenn, supra note 38 , at 342 . 
judiciary." ${ }^{, 41}$ That same year, Judge Robert Sprecher of the Seventh Circuit Court of Appeals similarly argued for greater compensation for federal judges, noting that the steep learning curve for federal judges meant that the resignation of an experienced judge results in a substantial societal cost. ${ }^{42}$ Like Justice Breyer, Judge Sprecher contended that inadequate compensation threatens the quality, and ultimately the independence and integrity, of the federal judiciary. ${ }^{43}$ More recently, Emily Field Van Tassel wrote a historical piece accounting for the various reasons that federal judges have left the bench. ${ }^{44}$ It is worth noting that in her study looking at judges who left the bench between 1789 and 1992, only eleven judges stated inadequate salary as their reason for leaving. ${ }^{45}$

Other scholarly works in the 1980s and 1990s on judicial tenure were more empirical in nature. The primary focus remained the Supreme Court. ${ }^{46}$ Two recent articles, however, have examined the issue of judicial tenure on lower federal courts, though both focused primarily on the relevancc of political factors. Deborah Barrow and Gary Zuk argued in their 1990 article that politics largely explained why judges retired from the bench. ${ }^{47}$ Specifically, they found that Dcmocratic judges at both the district and circuit court levels (those largely appointed by Democratic presidents) were more likely to depart during a Democratic president's administration, and were more likely to stay in the aftermath of "critical (liberal) Supreme Court decisions." 48 James Spriggs and Paul Wahlbeck likewise provided a political explanation in their 1995 article: judges were more likely to retire when they shared the same political affiliation as the sitting president. ${ }^{49}$ They also concluded that additional factors, including compensation, affected judges' retirement rates.

Chief Justice Rehnquist has also written on the subject. In his annual Year-End Reports on the Fcderal Judiciary, Rehnquist has repeatedly spoken critically of what he perceives as inadequate compensation for federal judges and its probable effects on tenure. He has argued that judges are squeezed in multiple directions: their caseloads have steadily increased due to the greater federalization of criminal and civil law as well as

41. Id.

42. Sprecher, supra note 38 , at 385.

43. Id. at 396.

44. See Emily Field Van Tassel, Resignations and Removals: A History of Federal Judicial Service-and Disservice-1789-1992, 142 U. PA. L. REv. 333 (1993). This article was based on a study conducted by Van Tassel and other scholars for the National Commission on Judicial Discipline and Removal.

45. See id. at 425 .

46. See supra note 36 .

47. Barrow \& Zuk, supra note 37.

48. Id. at 473 .

49. They also found that Democratic judges were more likely to leave when the Senate is controlled by the Democratic Party. See Spriggs \& Wahlbeck, supra note 37, at 592. 
unfilled vacancies remaining from prior departures, while at the same time their salaries have diminished in real dollars. ${ }^{50}$ This trend in declining compensation runs "counter-productive to the common sense goal of encouraging capable individuals to enter the Judiciary." "In his 2000 YearEnd Report, Rehnquist surmised that declining salaries have induced a higher number of judges to leave the bench in the I990s..$^{52}$ Rehnquist reiterated his concern regarding judicial pay more recently in his 2002 YearEnd Report. ${ }^{53}$

Other legal scholars have expressed skepticism over the causal relationship between judicial salary and tenure. Judge Richard Posner, for example, has described judicial compensation as "adequate," noting that the price differential between associates at large law firms and federal judges could be justified in part because associates "work like dogs, and most federal judges do not." 54 Moreover, he argued, pensions offered to federal judges that allow them to retire at full salary ${ }^{55}$ provide an attractive inducement, "more so with every passing year." Posner concedes that some highly qualified candidates, particularly those residing in areas with a high cost of living, might decline opportunities to join the federal bench. ${ }^{57}$ Other judicial scholars such as Pamela Karlan believe that, notwithstanding the fairness concerns underlying federal judicial compensation, "it would be ludicrous to suggest that current judicial salaries pose any sort of structural threat to judicial independence." $\$ 88$

From the existing scholarship emerge two points. First, political scientists who have undertaken analytical studies of the factors influencing judicial service have focused primarily on decisions motivating retirement rather than length of service, thus understandably placing a greater emphasis on examining political factors. ${ }^{59}$ Second, legal scholars have generally refrained from considering judicial service from an empirical perspective, instead examining more closely the doctrinal issues raised, such as separation of powers concepts underlying the decisions in the Williams case

50. Rehnquist, The 1997 Year-End Report on the Federal Judiciary, supra note 11.

51. Rehnquist, The 1998 Year-End Report on the Federal Judiciary, supra note 11.

52. Rehnquist, The 2000 Year-End Report on the Federal Judiciary, supra note 11, at 3 (writing that "it is no wonder" that fifty-four federal judges left the bench during the 1990s, given that many partners in "top firms in large cities now make in excess of $\$ 500,000$ per year").

53. Rehnquist, The 2002 Year-End Report on the Federal Judiciary, supra note 11 (stating that "the need to increase judicial salaries ha[s] again become the most pressing issue facing the Judiciary.").

54. POSNER, supra note 11 , at 29.

55. See 28 U.S.C. $\& 371(2002)$.

56. POSNER, supra note 11 , at 32-33.

57. Id. at 29 .

58. Pamela S. Karlan, Two Concepts of Judicial Independence, 72 S. CaL. L. Rev. 535, 538

59. See supra text accompanying note $47-49$. 
law. ${ }^{60}$ If anything, they-perhaps persuaded by Chief Justice Rehnquistassume a causal link between judicial salary and judicial service, a conclusion that is not yet supported by empirical evidence. In so doing, they have left unanswered the broader question: what factors influence how long federal judges stay on the bench? The remainder of this Article uses statistical analyses to address this question.

\section{III}

\section{A Description of the Data Relating to Judicial Tenure}

I explore factors influencing judicial tenure using data provided by the Federal Judicial Center. ${ }^{61}$ The complete data set includes information on every Article III judge-Supreme Court, court of appeals, district courtwho has served on the federal bench from 1789 through 2001. I focused on data from the period of $1945-2000$ because the courts during this period more closcly resemble the current federal judicial structure, making the data more relevant to contemporary issues of judicial compensation and tenure. ${ }^{62}$ Data on each judge includes relevant dates (birth, nomination, commission, and if applicable, retirement, departure, and death), gender, ethnicity, education, court, professional background (including occupation prior to joining the federal bench), American Bar Association ratings, and several other factors. Using other public and private data where possible, I added additional variables, such as net assets at the time of nomination, annual salary at time of retirement, and presidential and Senate-majority parties at the time of nomination and retirement. ${ }^{63}$

Within the I945-2000 period, I narrowed the data to all judges who retired from the bench between 1945 and 2000. By retirement, I mean a permanent departure from the bench; judges who elect senior status were

60. See, e.g., Williams v. United States, 122 S.Ct. 1221, 1225-26 (2002) (mem.) (Breyer, J., dissenting from denial of certiorari) (writing that Congress's reliance on Section 140 of the 1982 appropriations bill to reject the judges' claim for salary adjustment unfairly singles out judges); see also Thomas I. Vanaskie, The Independence and Responsibility of the Federal Judiciary, 46 VILL. L. REv. 745,773 (2001) (stating that "Congressional failure to abide by commitments made in the 1989 Ethics Reform Act makes it difficult to retain and recruit the caliber of persons needed to discharge the important responsibilities of the federal judiciary.").

61. Unless otherwise stated, the results reported in the tables and graphs discussed infra used electronic data provided by Steve Saltzgiver at the Federal Judicial Center.

62. I decided against looking at the entire twentieth century, sinee the eourts as well as society have structurally changed in dramatic ways over this period. Since 1 wanted to include complete presidential terms as much as possible, I chose 1945, the year the Truman administration began, as the start date.

63. Information about the president and Senate leadership at the times of nomination and confirmation is available on each judge's respective government webpage. See FED. Judicial History Office of the Fed. Judicial Ctr., Federal Judges Biographical Database at www.fjc.gov/history/home.nsf/judges_frm (last visited Mar. 31, 2003). Judicial salaries were found in the Judiciary Act of 1789 and subsequent acts. See supra note 11. Information about judges' net assets is public, compiled by Sheldon Goldman, profcssor of political science at University of Massachusetts. 
not classified as "retired" for purposes of this Article. ${ }^{64}$ Thus, while many of the judges included in the data set began and ended their federal judicial career within the 1945-2000 period, it also includes those who joined the bench prior to 1945 . The data set provides demographic information on judges who retired during each presidential administration and allows for regression analysis examining the causal factors underlying judicial tenure. Ultimately, looking at the data by administration is a helpful way of observing why judges serve on the bench for the duration that they do, allowing us to examine political, as well as economic and chronological, data.

\section{IV \\ Explanations of Judicial Tenure}

There are several possible explanations for judicial tenure. Just as politics influence which judges gain confirmation, so too might politics influence when judges leave the bench. Similarly, financial compensation may affect judges' willingness to remain on the bench, or motivate them to pursue employment elsewhere. Lastly, personal characteristics, such as age, gender, and ethnicity, may explain trends in judicial tenure. Part IV explores these factors.

\section{A. Overview}

Table 2 provides the aggregate average data for federal district and circuit court judges who retired between 1945 and 2000:

64. In measuring judicial tenure, judges who permanently leave one level of the court after being elevated to a higher court (for example, district court to circuit court) are counted within the group of judges who permanently leave to pursue nonjudieial activities (for example, retirement). The effeet of classifying elevated judges in the same category, if any, would be to understate the actual tenure trends. As later discussed, the figures show that judicial tenure on both the district and circuit courts has slightly increased over the $1945-2000$ period. Had elevated judges been excluded from consideration, the figures for judicial tenure would be even higher. 
TABLE 2

SUMmary StaTistics (Average)

Characteristics of Retired Federal Judges, 1945-2000

$(\mathrm{N}=1271)$

$$
\begin{gathered}
\text { Judges } \\
\text { Retired } \\
1945- \\
2000
\end{gathered}
$$

\section{Chronology}

Commisslon Age

Age of Senior Status

Retirement Age

Tenure on Bench

Qualified for Pension

\section{Demographics}

Percent Femaie

Percent Biack

Percent Hispanic

Harvard/Yaie Law Graduate
52.2

(7.6094)

70.9

(5.6508)

70.5

(13.1707)

18.3

(11.5911)

$53.7 \%$

(.4989)

$3.1 \%$

$(0.1725)$

$3.1 \%$

$(0.1725)$

$1.4 \%$

$(0.1182)$

$13.3 \%$

$(0.3397)$
Judges

Retired

1945-

2000

Job Held Before Joining Bench Judge

$37.1 \%$

$(0.4831)$

Private Practice

$38.9 \%$

$(0.4877)$

Prosecutor

$11.4 \%$

(0.3188)

Government

$5.7 \%$

$(0.2328)$

Legislator

$3.7 \%$

(0.1888)

Politics

Nominated by Democratic

President

$\mathbf{5 2 . 9 \%}$

(0.4994)

Retlred during Democratic

Presidency

(0.5001)

Note: Standard deviations are in parentheses.

On average, judges were appointed during their early fifties and served on the bench for nearly twenty years. More than half of them qualified for their pension, which allowed them to retire at full pay ${ }^{65}$ Most of the judges came either from private practice or from another judgeship (either federal or state), although a nontrivial percentage came from a prosecutor's office (U.S. Attorney or District Attorney), civil service, or elected office ("Legislator"). Moreover, the federal bench during this period, like the other branches of the federal government, consisted primarily of Caucasian men, with very few women, Black, or Hispanic attorneys. With recent appointments, women and minority groups have dramatically increased their representation. ${ }^{66}$ Because these statistics are aggregated, they cannot capture trends over time. To observe whether tenure trends have 86.

65. The pension qualification requirements for federal judges are explained in detail, infra note

66. In fact, between 1945 and 2000 , the proportional representation of judges in the abovementioned groups of judges has doubled. 
changed over time, and if so, by how much, it is necessary to disaggregate the data.

\section{B. Time-Series Trends}

Tables $3 \mathrm{a}$ and $3 \mathrm{~b}$ show the demographic data, broken down by presidential administration.

TABLE 3A

Summary Statistics-Presidential Administration

Characteristics of Retiring District Court Judges, 1945-2000

\begin{tabular}{|c|c|c|c|c|c|c|c|c|c|c|c|c|c|}
\hline \multirow[b]{2}{*}{ Years } & \multirow[b]{2}{*}{ President } & \multirow[b]{2}{*}{$\mathbf{N}$} & \multirow[b]{2}{*}{$\begin{array}{c}\text { Comm } \\
\text {-ision } \\
\text { Age }\end{array}$} & \multirow[b]{2}{*}{$\begin{array}{c}\text { Senior } \\
\text { Status } \\
\text { Age }\end{array}$} & \multirow[b]{2}{*}{$\begin{array}{c}\text { Retire- } \\
\text { ment } \\
\text { Age }\end{array}$} & \multirow[b]{2}{*}{ Tenure } & \multirow[b]{2}{*}{$\begin{array}{l}\text { Quall- } \\
\text { fied for } \\
\text { Pension }\end{array}$} & \multirow[b]{2}{*}{ Female } & \multirow[b]{2}{*}{ Biack } & \multicolumn{4}{|c|}{$\begin{array}{c}\text { Job Prior to Joining the } \\
\text { Bench }\end{array}$} \\
\hline & & & & & & & & & & $\begin{array}{l}\text { His- } \\
\text { panlc }\end{array}$ & Judge & $\begin{array}{l}\text { Private } \\
\text { Practice }\end{array}$ & $\begin{array}{l}\text { Prose } \\
\text { cutor }\end{array}$ \\
\hline $1945-1953$ & Truman & 83 & 51 & 72 & 65 & 15 & $31 \%$ & $0 \%$ & $0 \%$ & $0 \%$ & $20 \%$ & $46 \%$ & $18 \%$ \\
\hline 1953-1961 & Eisenhower & 91 & 53 & 73 & 71 & 18 & $52 \%$ & $0 \%$ & $0 \%$ & $0 \%$ & $25 \%$ & $43 \%$ & $16 \%$ \\
\hline 1961-1963 & Kennedy & 44 & 50 & 78 & 67 & 18 & $32 \%$ & $0 \%$ & $0 \%$ & $0 \%$ & $11 \%$ & $64 \%$ & $14 \%$ \\
\hline 1963-1969 & Johnson & 94 & 51 & 74 & 68 & 16 & $47 \%$ & $0 \%$ & $2 \%$ & $0 \%$ & $37 \%$ & $40 \%$ & $11 \%$ \\
\hline $1969-1974$ & Nixon & 95 & 53 & 72 & 69 & 16 & $44 \%$ & $0 \%$ & $0 \%$ & $1 \%$ & $33 \%$ & $35 \%$ & $16 \%$ \\
\hline $1974-1977$ & Ford & 51 & 52 & 71 & 70 & 17 & $55 \%$ & $0 \%$ & $0 \%$ & $0 \%$ & $18 \%$ & $49 \%$ & $24 \%$ \\
\hline $1977-1981$ & Carter & 70 & 51 & 71 & 64 & 13 & $37 \%$ & $1 \%$ & $7 \%$ & $3 \%$ & $33 \%$ & $41 \%$ & $7 \%$ \\
\hline $1981-1989$ & Reagan & 155 & 50 & $\cdot 70$ & 68 & 18 & $54 \%$ & $6 \%$ & $3 \%$ & $2 \%$ & $34 \%$ & $46 \%$ & $10 \%$ \\
\hline $1989-1993$ & Bush, Sr. & 99 & 50 & 69 & 69 & 19 & $60 \%$ & $8 \%$ & $3 \%$ & $5 \%$ & $33 \%$ & $44 \%$ & $11 \%$ \\
\hline $1993-2000$ & Clinton & 188 & 51 & 68 & 75 & 24 & $78 \%$ & $7 \%$ & $7 \%$ & $4 \%$ & $41 \%$ & $40 \%$ & $10 \%$ \\
\hline
\end{tabular}

Note: President corresponds to the presidential administration during which time the judge retired from the bench.

The figures for district court retirements reveal that, on average, recent retirees from the bench were appointed at a marginally younger age and served slightly longer terms on the bench than did their predecessors. Accordingly, a greater number of them qualified for their pension, from a low of $31.3 \%$ of judges retiring during the Truman administration to $78.2 \%$ of judges retiring during the Clinton administration. While some of this increased duration on the bench can be attributed to higher life expectancies, that alone cannot account for the entire increase. ${ }^{67}$

Additionally, while an overwhelming majority of judges joined the bench from a prior judgeship, private practice, or the prosecutor's office, Table 3a shows some shifting in the distribution among the three. The percentage of judges coming from private practice has held fairly constant, but over time more judges have come from a prior judgeship and fewer from prosecutors' offices. One possible explanation for the increase in representation in prior judgeships is that service on the bench allows both the president and the Senate to observe the judicial philosophy of the nominee and better predict how the judge will act once on the federal bench.

67. See infra text and figures accompanying notes 68-72. 
Table $3 b$ provides comparable data for circuit court judges. It illustrates some differences between circuit and district court judges, but produces similar trends over time:

\section{TABLE 3B}

Summary Statistics - Presidential Administration

Characteristics of Retiring Circuit Court Judges, 1945-2000

\begin{tabular}{|c|c|c|c|c|c|c|c|c|c|c|c|c|c|}
\hline \multirow[b]{2}{*}{ Years } & \multirow[b]{2}{*}{ President } & \multirow{2}{*}{\multicolumn{2}{|c|}{$\begin{array}{c}\text { Comm- } \\
\text { ision }\end{array}$}} & \multirow[b]{2}{*}{$\begin{array}{c}\text { Senior } \\
\text { Status } \\
\text { Age }\end{array}$} & \multirow[b]{2}{*}{$\begin{array}{c}\text { Retire- } \\
\text { ment } \\
\text { Age }\end{array}$} & \multirow[b]{2}{*}{ Tenure } & \multirow[b]{2}{*}{$\begin{array}{l}\text { Qualified } \\
\text { for Pen- } \\
\text { sion }\end{array}$} & \multirow[b]{2}{*}{ Female } & \multicolumn{5}{|c|}{$\begin{array}{l}\text { Job Prior to Joining the } \\
\text { Bench }\end{array}$} \\
\hline & & & & & & & & & Black & $\begin{array}{l}\text { His- } \\
\text { panic }\end{array}$ & Judge & $\begin{array}{l}\text { Private } \\
\text { Practice }\end{array}$ & $\begin{array}{l}\text { Prose- } \\
\text { cutor }\end{array}$ \\
\hline 1945-1953 & Truman & 22 & 56 & 75 & 71 & .15 & $50 \%$ & $0 \%$ & $0 \%$ & $0 \%$ & $50 \%$ & $18 \%$ & $18 \%$ \\
\hline 1953-1961 & Eisenhower & 24 & 57 & 78 & 70 & 13 & $33 \%$ & $0 \%$ & $0 \%$ & $0 \%$ & $63 \%$ & $21 \%$ & $0 \%$ \\
\hline $1961-1963$ & Kennedy & 11 & 56 & 79 & 83 & 27 & $100 \%$ & $0 \%$ & $0 \%$ & $0 \%$ & $36 \%$ & $18 \%$ & $18 \%$ \\
\hline $1963-1969$ & Johnson & 17 & 57 & 74 & 75 & 18 & $71 \%$ & $6 \%$ & $6 \%$ & $0 \%$ & $65 \%$ & $24 \%$ & $0 \%$ \\
\hline 1969-1974 & Nixon & 26 & 54 & 70 & 70 & 16 & $50 \%$ & $0 \%$ & $0 \%$ & $0 \%$ & $50 \%$ & $19 \%$ & $8 \%$ \\
\hline $1974-1977$ & Ford & 14 & 51 & 70 & 76 & 25 & $79 \%$ & $0 \%$ & $7 \%$ & $0 \%$ & $71 \%$ & $14 \%$ & $0 \%$ \\
\hline $1977-1981$ & Carter & 24 & 54 & 71 & 76 & 21 & $71 \%$ & $4 \%$ & $4 \%$ & $0 \%$ & $67 \%$ & $21 \%$ & $0 \%$ \\
\hline $1981-1989$ & Reagan & 62 & 57 & 70 & 71 & 15 & $60 \%$ & $2 \%$ & $2 \%$ & $0 \%$ & $50 \%$ & $39 \%$ & $6 \%$ \\
\hline $1989-1993$ & Bush, Sr. & 23 & 53 & 69 & 72 & 19 & $70 \%$ & $4 \%$ & $4 \%$ & $0 \%$ & $52 \%$ & $35 \%$ & $4 \%$ \\
\hline $1993-2000$ & Ciinton & 58 & 57 & 70 & 79 & 22 & $86 \%$ & $5 \%$ & $10 \%$ & $0 \%$ & $52 \%$ & $26 \%$ & $9 \%$ \\
\hline
\end{tabular}

Note: President corresponds to the presidentiai administration during which time the judge retired from the bench.

The president and Senate often select a circuit court nominee from the pool of district court judges, as reflected in the distribution of prior jobs: the majority come from the bench, a large plurality from private practice, and relatively few directly from prosecutors' offices. Thus, circuit court judges, on average, are older than their district court counterparts when they begin their commission. Yet, despite being older when they join the bench, circuit court judges serve roughly the same period on the bench as their district court counterparts. Not surprisingly, a high percentage of circuit court judges qualify for their pension upon retirement.

Two explanations may account for this phenomenon. First, circuit judges, by the nature of their position, hear cases for which litigants disagree over the earlier district court outcome. As a result, they often rule on more controversial, and hence more significant, cases. Second, the workload is less hectic on a daily basis for circuit court judges: they need not meet with litigants outside of oral argument or engage in the fact-finding inquiry inherent in most district level cases. These factors may allow circuit court judges to work for a longer time.

Taken together, Tables $3 \mathrm{a}$ and $3 \mathrm{~b}$ show that while retirement trends for both district and circuit judges have been cyclical over time, the trend in recent years is towards longer years of service and a corresponding increase in the number of judges qualifying for their pension. Admittedly, this upward trend may be part of a cycle and eventually turn downward. But the recent trend is clearly not toward abbrcviated tenure, as some, like 
Chief Justice Rehnquist, have contended. Figure 4 provides an annual trend line for commission age, tenure, and the percentage of judges who qualified for their pension.

\section{Figure 4}

Average Commission Age, Length of Tenure, and

Rate of Pension Qualification, 1945-2000

3-Year Rolling AVERaGe ${ }^{68}$

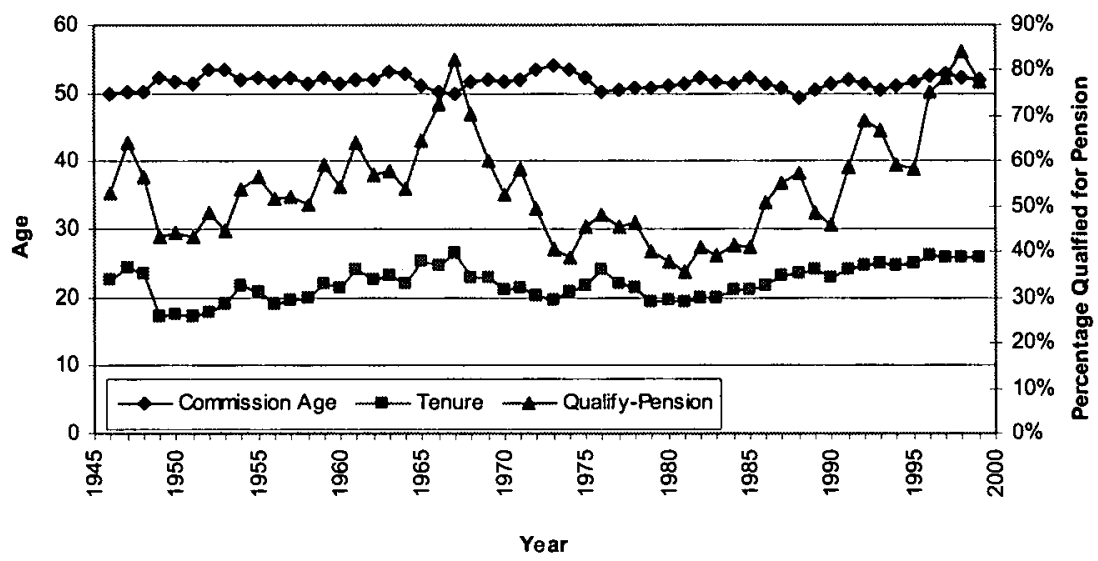

Note: Commission Age and Tenure are measured in years, the left-side y-axis; the Qualify Pension line measures the percentage of retining judges who qualified for their pension, the right-side $y$-axis.

The average age at commission has held fairly constant, between fifty and fifty-five years of age, while the average length of tenure has slowly but steadily increased over the last two decades, exceeding twenty years for the past decade. Similarly, the percentage of judges qualifying for their pension has steadily increased, nearly monotonically during the 1980 s and 1990s.

One explanation for the increase in tenure, of course, is the overall increase in life expectancy. 1t would naturally follow that, as the general population lives longer on average, judges likewise work additional years on the bench. Since 1945, life expectancy has increased about ten years. ${ }^{69}$ As illustrated in Figure 5, the average age of federal judges who remain on the bench each year has held fairly constant, between 61 and 65 years of age. The less-than-expected increase in the average age of sitting judges at

68. Figures 4-6 use a three-year rolling average to better reflect the long-term trends. Given the relatively low number of judges that may join the bench in any given year (particularly in earlier years), an "outlier" judge may have a dramatic, and potentially misleading, effect on the figures for a given year.

69. Statistics on life expectancy were obtained from the National Center for Health Statistics. Nat'l Ctr. for Health Statistics, U.S. Dep't Health and Human Serv., 50 National Vital STATISTICS REPORT 34 tbl.12 (Mar. 21, 2002), available at http://www.cdc.gov/nchs/data/nvsr/nvsr50/ nvsr50_06.pdf. 
first appears incongruous, given that federal judges are serving longer terms on the bench. This can be largely explained by the small but significant trend among recent presidents to appoint younger men and women to the bench. ${ }^{70}$

\section{Figure 5}

Comparison of Retiring vs. Remaining Judges, 1945-2000

\section{3-Year Rolling Average ${ }^{71}$}

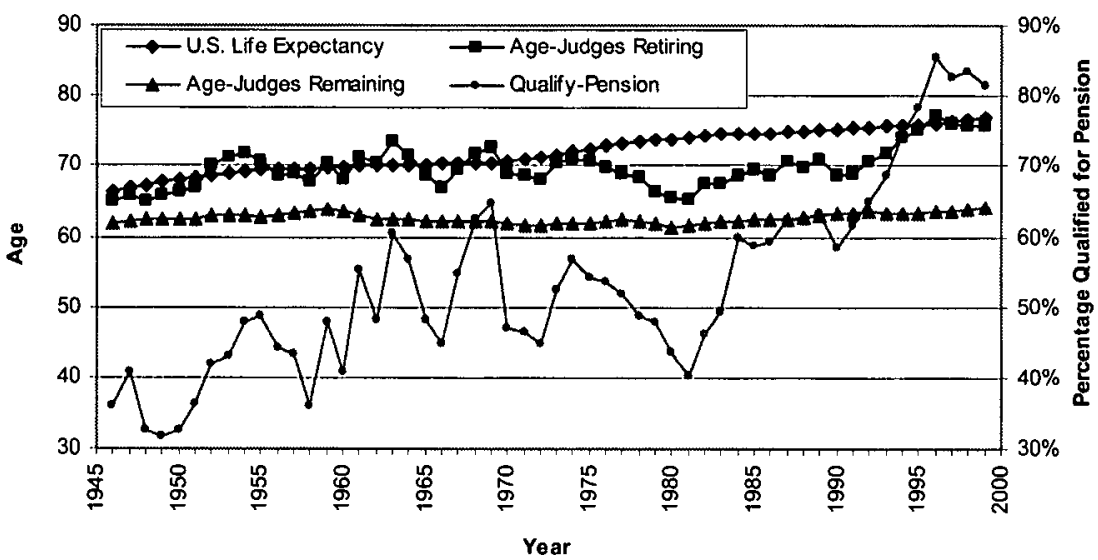

Note: U.S. Life Expectancy, Age of Judges Remaining, and Age of Judges Departing are measured by the left-side y-axis; the Qualify-Pension line measures the percentage of retiring judges who qualified for their pension, the right-side $y$-axis.

Of perhaps greater interest is the avcrage (mean) age for judges at rctirement, which has outpaced the increase in U.S. life expectancy over the past twenty years. Consistent with Tables $3 a$ and $3 b$, Figure 5 shows that the retiremcnt age has increascd over the past two decades. Not

70. The average age of appointed (not retiring) federal judges, broken down by presidential administration:

Nominating President
Truman
Eisenhower
Kennedy
Johnson
Nixon
Ford
Carter
Reagan
Bush, Sr.
Cilnton

$\begin{array}{cc}\text { District Court } & \text { Circult Court } \\ 52.4 & 55.8 \\ 52.6 & 56.2 \\ 52.2 & 54.4 \\ 51.8 & 52.6 \\ 49.7 & 54.4 \\ 49.4 & 51.5 \\ 50.3 & 52.5 \\ 49.3 & 50.6 \\ 48.8 & 49.7 \\ 50.2 & 52.5\end{array}$

In both the district and circuit courts, average age at commission has declined over the past half century, although not monotonically. Figures are generated from data provided by the Federal Judicial Center.

71. Figures on average life expectancy refer to expectation of life at birth for all males and females for that given year. 
surprisingly, the trend line for judges' average age at retirement closely tracks the trend line for percentage of judges qualifying for pension.

Those who believe that inadequate salaries compel judicial departures point to individual judges who have left the bench at relatively young ages for financial reasons. ${ }^{72}$ It is these early departures, they intimate, that reflect the deleterious effects of inadequate salaries. But, as Figure 6 illustrates, early departures from the federal judiciary are not a recent phenomenon.

\section{Figure 6}

RETIRING JUDGES, 1945-2000

\section{3-Year Rolling Average}

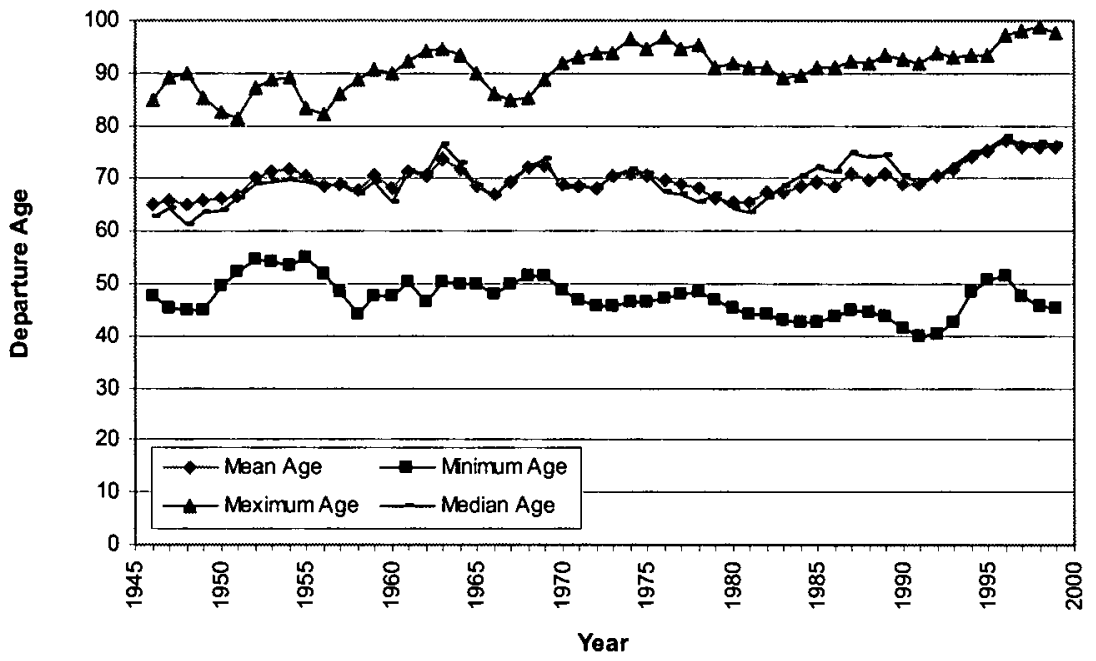

This figure shows the following: the oldest judge to retire from the bench in each given year (Maximum Age), the youngest judge to retire from the bench in each given year (Minimum Age), the mean age for all retiring judges in each given year, and the median age for all retiring judges.

72. A number of judges have taken an early retirement from the bench to increase their salaries. Former Judge Joe Kendall of the Northern District of Texas left the bench to join a large law firm. See Seth Stern, A Career as a Federal Judge Isn't What It Used to Be, Christian Sci. Monitor, Jan. 22, 2002, at 1. Former Chief Judge Edward Davis of the Southern District of Florida reportedly left the bench to earn a higher salary. Glater, supra note 2. Timothy K. Lewis, formerly of the U.S. Court of Appeals for the Third Circuit, left the bench to join a large litigation law firm. Ann Belser, U.S. Judge Resigning July I to Join Buchanan Ingersoll, PitTsBURGH GAZETTE, Apr. 28, 1999, at B2. Raul Ramirez, formerly of the Eastern District of California, left the bench after ten years for private practice to better provide for his family. Saundra Torry, Some Judges Decide a Lifetime on the Federal Bench Is Too Long, WASH. Post, Jan. 20, 1992, at F5. Emery Sneeden of the Circuit Court of Appeals for the Fourth Circuit resigned to provide for his grandchildren. Bill McAllister, The Judiciary's 'Quiet Crisis': Prestige Doesn't Pay the Tuition, WASH. Post, Jan. 21, 1987, at A19. 
Jurists such as Justice Breyer decry the use of a federal judgeship as a "stepping-stone to some other more lucrative job in the private sector."73 As the bottom line (Minimum Age) of Figure 6 illustrates, dating back to at least since 1945 , some judges have left the federal judiciary at a relatively young age, for whatever pursuit. These early departures, however, have been balanced by those who serve into their nineties. On average, judges serve until their midseventies, long after most citizens have retired from their jobs. It is also worth noting that the average age and median age for retiring judges closely align, casting doubt whether the average age of retirement is being driven by "outlier" judges who retire at a very old age.

\section{Regression Analysis}

The tables and figures in Part IV.B strongly suggest that over the past fifty years, federal judges were appointed to the bench at a slightly younger age and served longer terms on the bench. Even if federal judges were dissatisfied with the declines in their real salaries, ${ }^{74}$ their dissatisfaction does not appear to manifest in earlier retirement or shorter terms on the bench, at least not compared to earlier years. To better ascertain whether judicial service has changed over time, and, if so, which factors have influenced it, it is helpful to evaluate the data through regression analysis. This approach allows for greater precision in evaluating the individual effects of particular variables, the significance of these effeets, and the possible changes over time.

Table 4a reports the regression of federal district judges, looking at the factors that influence the number of years that judges serve on the bench.

73. Time of Crisis, supra note 1 (statement of Justice Breyer).

74. See, e.g., Van Tassel, supra note 44 , at 425 (listing how some judges have left the bench due to inadequate salary). 


\section{TABLE 4A \\ REgRESSION ANALYSIS \\ ReTiRed District Court Judges, 1945-2000 \\ (Dependent) Variable of Interest: Years on the BenCh \\ $(\mathrm{N}=962)$}

\begin{tabular}{lcccccc} 
Independent Variables & Coef. & Std. Err. & $\mathbf{t}$ & \multicolumn{2}{c}{$\mathbf{P}>|\mathbf{t}|$} & [95\% Conf. Interval] \\
Female & -8.457 & 2.082 & -4.060 & $\mathbf{0 . 0 0 0}$ & -12.542 & -4.371 \\
Black & -3.888 & 2.244 & -1.730 & $\mathbf{0 . 0 8 3}$ & -8.292 & 0.515 \\
Age at Commission & -0.124 & 0.053 & -2.340 & $\mathbf{0 . 0 1 9}$ & -0.228 & -0.020 \\
Nominated by Democrat President & 2.574 & 0.739 & 3.480 & $\mathbf{0 . 0 0 1}$ & 1.124 & 4.024 \\
Prior Job & & & & & & \\
$\quad$ Elected Official & -2.446 & 5.880 & -0.420 & 0.678 & -13.985 & 9.093 \\
$\quad$ Judge & -4.005 & 5.709 & -0.700 & 0.483 & -15.209 & 7.199 \\
$\quad$ Government & 2.446 & 5.898 & 0.410 & 0.678 & -9.129 & 14.021 \\
$\quad$ Private Practice & -2.809 & 5.702 & -0.490 & 0.622 & -13.999 & 8.380 \\
$\quad$ Professor & -9.709 & 6.673 & -1.450 & 0.146 & -22.805 & 3.386 \\
$\quad$ Prosecutor & -3.663 & 5.780 & -0.630 & 0.526 & -15.006 & 7.680 \\
Constant & 26.591 & 6.463 & 4.110 & 0.000 & 13.907 & 39.274
\end{tabular}

Note: A P-value less than or equal to 0.10 is generally regarded as statistically significant. 'Elected Official' refers to whether the judge held elected office prior to joining the bench.

Gender and ethnicity have a large and statistically significant effect on the length of service on the bench. Women served, on average, 8.5 fewer years on the bench than their male counterparts, and Black judges served 3.9 years less than their non-Black counterparts. This contrast is made more crucial by the fact that both female and Black judges began their judgeships at a younger age than their male and non-Black counterparts. ${ }^{75}$ One must look at these figures with caution, since women and Blacks comprise only a very small fraction-7.1\%—of all judges who left the bench during this period. ${ }^{76}$ District court judges appointed by Democratic presidents serve on average two more years than their Republican-appointed brethren. ${ }^{77}$ Judges' ages at commission had a small, but statistically significant,

75. The data reveals that the average age for Black nominees joining the district court is $\mathbf{4 9 . 2}$ years of age versus 51.3 years of age for non-Black nominees. The average age for female nominees joining the district court is 47.2 years of age versus 51.3 years of age for male nominees.

76. A comprehensive inquiry explaining the differential tenure trends among female and Black judges is beyond the seope of this Article, but breaking down net assets by gender and race among those nominated to the bench between 1977-2000 shows that Black judges have lower net assets than non-Black judges. See supra note 63 (describing Goldman data). Perhaps Black judges serve shorter terms on the bench because they, more than their non-Black colleagues, feel financial pressures to leave the bench to earn more in private practice. This theory, however, cannot explain shorter tenure rates among women judges, since their net assets were higher than those of their male counterparts. This is only speculation at this point, requiring further research.

77. An explanation underlying this effect is beyond the scope of this Article, but it may be because Republican presidents during the period 1945-2000 were in office for thirty-six of the fifty-five years. Democrat-appointed judges who desired that their successor be of the same political affiliation may have remained longer on the bench, waiting-often without satisfaction-for a change in leadership in the White House. 
effect on overall service-judges appointed later in life served shorter terms.

More surprisingly, a judge's occupation prior $^{78}$ to joining the district court does not have a statistically significant effect on his or her length of service. This is significant because a judge's job prior to joining the bench can be used as a rough proxy for individual wealth. ${ }^{79}$ One might expect, all things being equal, that judges coming directly from private legal practice are more affluent than those coming from either government or another judgeship, since private practice is typically more lucrative than the other professions. ${ }^{80}$ One might also expect that judicial compensation would have a less negative effect on judicial service for wealthier judges because they have a diminishing marginal utility for money. ${ }^{81}$ Accepting the validity of this proxy, the nonsignificance of a judge's prior job suggests a low elasticity between a judge's wealth and his or her length of service on the bench. Differences in a judge's prior wealth do not yield corresponding differences in the length of a judge's tenure. Alternatively, a judge's prior job may not be a valid proxy for wealth, which would suggest that judges from different career backgrounds may be similar with respect to wealth. This latter question I explore shortly.

Rerunning the regression by accounting for trends by presidential administrations-done by including dummy variables for each of the presidential administrations-does not statistically significantly affect the results. Gender, ethnicity, age at commission, and political affiliation of the nominating president remain statistically significant, with similar coefficients as reported in Table $4 \mathrm{a}$. The other variables remain statistically nonsignificant, also with similar coefficients. The results also show that the decline in tenure during the Carter administration, and the increase in tenure during the Clinton administration, were indeed statistically significant, as suggested in Table 3a.

78. A brief explanation regarding the categories for prior occupation: "Government" means a nonelected government position; "Judge" refers to a judgeship, whether state or federal; "Elected Official" means an elected position in the state legislature or Congress; "Private Practice" corresponds to a job at a law firm or nongovernment job; "Professor" refers to a university professorship or deanship; "Prosecutor" means a job at either the city, district, state, or U.S. attorney's office.

79. Neither the data provided by the Administrative Offiee of the U.S. Courts nor other publicly available sources recorded the wealth of individual judges. But beginning with Carter judicial appointees, Shcldon Goldman began colleeting information on judges' net assets at time of nomination. Later in this Article, infra tbl.5, 1 use this information in a duration model to test the effect of wealth on judicial service for judges appointed after 1976.

80. The disparity between private practice, government, and public-interest practice is more pronounced now than it was in prior decadcs. Given its longitudinal nature, the data may mask recent effects.

81. Of course, one could also argue that an individual with higher net assets, assuming they were based on salary and not inheritance, would have a higher opportunity cost in foregoing his or her job to join the federal bench. 
The identical regression, looking at circuit court judges, produces similar results:

\section{TABLE 4B \\ REGRESSION ANALYSIS \\ Retired Circuit Court Judges, 1945-2000 \\ (DEPENDENT) VARIable OF INTEREST: Years ON THE BENCH \\ $(\mathrm{N}=\mathbf{2 8 2})$}

$\begin{array}{lcccccc}\text { Independent Variables } & \text { Coef. } & \text { Std. Err. } & \mathbf{t} & \mathbf{P}>|\mathbf{t}| & \text { [95\% Conf. Interval] } \\ \text { Female } & -8.219 & 4.605 & -1.780 & \mathbf{0 . 0 7 5} & -17.286 & 0.847 \\ \text { Black } & -8.441 & 3.453 & -2.440 & \mathbf{0 . 0 1 5} & -15.240 & -1.643 \\ \text { Age at Commission } & -0.440 & 0.086 & -5.110 & \mathbf{0 . 0 0 0} & -0.609 & -0.270 \\ \text { Nominated by Democrat President } & -0.006 & 1.353 & 0.000 & 0.997 & -2.670 & 2.658 \\ \text { Prior Job } & & & & & & \\ \quad \text { Elected Official } & -5.529 & 12.637 & -0.440 & \mathbf{0 . 6 6 2} & -30.407 & 19.350 \\ \quad \text { Judge } & -7.371 & 11.923 & -0.620 & 0.537 & -30.844 & 16.102 \\ \quad \text { Government } & -10.334 & 12.233 & -0.840 & 0.399 & -34.418 & 13.750 \\ \quad \text { Private Practice } & -7.693 & 11.979 & -0.640 & 0.521 & -31.277 & 15.891 \\ \quad \text { Professor } & -6.296 & 12.239 & -0.510 & 0.607 & -30.391 & 17.799 \\ \quad \text { Prosecutor } & -6.377 & 12.216 & -0.520 & 0.602 & -30.428 & 17.674 \\ \text { Constant } & 50.898 & 12.982 & 3.920 & 0.000 & 25.338 & 76.457\end{array}$

Note: A P-value less than or equal to 0.10 is generally regarded as statistically significant. 'Elected Official' refers to whether the judge held elected office prior to joining the bench.

Female and Black circuit judges served statistically shorter terms, as did their counterparts on the district court. This differential impact occurred even though female and Black circuit judges began their commission at a younger age than their male and non-Black, respectively, counterparts. Age at commission again had a statistically significant but small effect on service. By contrast, political affiliation had a very small and statistically insignificant effect, suggesting that circuit court judges were perhaps even less affected by political factors than district court judges. As with the regression of district court judges, the judge's job prior to joining the bench did not yield any statistically significant results. Rerunning the regression to account for presidential trends did not significantly affect the results.

The regression for circuit court judges in Table $4 \mathrm{~b}$ raises the issue of whether the results vary by circuit. The intuition here is that tenure trends vary, even if only slightly, by eircuit, and that these differenees may be explained by differences in cost of living or alternative eareers to the bench. For example, all circuit judges earn the same salary, irrespective of where they reside. But the average cost of living for a judge in, say, the Tenth Circuit is likely lower than for a D.C. Circuit judge. Rerunning the regressions to account for circuit affiliation-by including a series of dummy variables for the respective circuit courts-does not change the results in a statistically significant way. 
Tables $4 \mathrm{a}$ and $4 \mathrm{~b}$ show that a judge's gender, race, and age affected how long he or she served on the bench. Political affiliation played a smaller and, in the case of circuit judges, statistically insignificant factor. For both courts, a judge's prior job did not affect the length of tenure on the bench. These regressions are consistent with the tables and figures in Part IV.B, but show with greater precision the differential impact of a judge's individual characteristics on tenure. Thus, with respect to federal judges who have left the bench over the past fifty-five years, judicial tenure has remained fairly constant, notwithstanding the decline in real salary over that period. Moreover, judicial tenure does not depend on a judge's prior employment, a factor that arguably can serve as a rough proxy for wealth.

\section{Wealth and Recent Appointments}

The above analysis cannot fully explain the effect, if any, of a judge's wealth on judicial service. The lack of financial data on judges during the I945-2000 period prevents a more precise inquiry on this issue. It is, however, possible to at least examinc the wealth of appointees during recent presidential administrations (President Carter through President Clinton) using data provided by judicial scholar Sheldon Goldman, who recorded federal judges' net assets at the time of their nomination.

\section{TABLE 5}

Net Assets (Constant 2000 Dollars) at Time of Nomination Federal Judges, 1977-2000

District Court

Total Average Assets
Prior Job
Government
Judge
Legisiator
Private Practice
Professor
Prosecutor

\section{Circuit Court}

Totai Average Assets
Prior Job
Government
Judge
Legislator
Private Practice
Professor
Prosecutor

$\begin{array}{rrrr}\begin{array}{c}\text { Carter } \\ \$ \mathbf{8 8 4 , 6 0 5}\end{array} & \begin{array}{c}\text { Reagan } \\ \mathbf{\$ 1 , 1 6 7 , 4 6 4}\end{array} & \begin{array}{c}\text { Bush, } \mathbf{S r} . \\ \mathbf{\$ 1 , 3 8 4 , 5 2 2}\end{array} & \begin{array}{c}\text { Clinton } \\ \mathbf{\$ 1 , 4 7 1 , 4 0 9}\end{array} \\ - & & & \\ \$ 637,518 & \$ 799,715 & \$ 272,576 & \$ 1,540,309 \\ \$ 378,428 & \$ 1,363,081 & - & \$ 2,405,442 \\ \$ 1,184,807 & \$ 1,539,404 & \$ 1,986,303 & \$ 2,272,722 \\ \$ 352,698 & \$ 1,180,071 & \$ 794,629 & \$ 884,688 \\ \$ 483,584 & \$ 792,577 & \$ 1,530,616 & \$ 1,201,103\end{array}$

$\begin{array}{rrrc}\begin{array}{c}\text { Carter } \\ \$ 1,752,802\end{array} & \begin{array}{c}\text { Reagan } \\ \$ 1,120,741\end{array} & \begin{array}{c}\text { Bush, Sr. } \\ \$ 1,835,584\end{array} & \begin{array}{c}\text { Ciinton } \\ \$ 2,963,074\end{array} \\ - & & & \\ \$ 1,172,856 & \$ 1,025,470 & \$ 1,878,165 & \$ 3,087,813 \\ \$ 660,574 & \$ 716,813 & - & - \\ \$ 2,974,244 & \$ 1,504,786 & \$ 2,384,180 & \$ 2,542,591 \\ \$ 997,333 & \$ 983,050 & - & \$ 4,317,415 \\ - & \$ 887,447 & \$ 245,030 & \$ 2,067,244\end{array}$

Note: Data provided by Sheldon Goldman, Department of Political Science, University of Massachusetts. 
The trends are similar across district and circuit court judges. Although there is some fluctuation in the judges' net wealth over time with respect to prior jobs, judges' wealth has generally increased in each successive administration. Because the figures are reported in constant, inflationadjusted dollars, this upward trend reflects that over time, judges, on average, joined the bench with more individual wealth. This holds true for judges joining the bench from either private practice or another judgeship (the two categories that comprise the large percentage of judges' jobs prior to joining the bench). While these figures, by themselves, cannot tell a definitive story about the effects of wealth on judicial tenure, they do reveal that over the past quarter century, presidents have, on average, appointed judges with higher personal wealth. Moreover, that increase is not attributable solely to attorneys coming from private practice but reflects a prevailing trend across different law-related jobs.

One must be cautious, however, in drawing conclusions from this data. The observed increase in net assets may largely wash away once eompared with salaries of attorneys over this period. The limited data on law school deans and large firm partners, as illustrated in Figure 3, suggests that judges' peers on the bar have also enjoyed increased wealth in recent years. This suggests that the increases in judges' net assets reflect a broader trend of increased wealth among other segments of the practicing bar, as well as comparable sectors of the economy.

\section{Is Compensation Affecting Tenure?}

This empirical analysis of federal district and circuit court judges over the past half century shows that trends in judicial service have held fairly constant. If there is a distinguishing trend, it is that judges are appointed at a slightly earlier age and serve slightly longer terms before retiring. These results run counter to Chief Justice Rehnquist's claim that judicial salaries are in effect shortening judges' length of service. Also, as illustrated by Tables $4 \mathrm{a}$ and $4 \mathrm{~b}$, a judge's job prior to joining the bench does not appear to affect in any statistically meaningful way his or her tenure on the bench.

At least some judges are likely dissatisfied with the decline in their real salaries, especially as the disparity between what they and their peers-let alone their former clerks-are earning continues to grow. In an effort by some judges to "keep up with the Joneses," 82 they are becoming increasingly discontent. Collectively, however, they do not appear to be

82. See Robert H. Frank, Choosing the Right Pond: Human Behavior and the Quest FOR STATUS (1985) (discussing the inherent need of individuals to compare themselves with a peer group, often with respect to salary). 
"voting with their feet" ${ }^{83}$ by leaving the federal beneh either after shorter tenures or at younger ages.

Why this cffect? There are at least two possible, nonmutually exclusive explanations. First, as suggested by the data on net assets for recent appointments, the downward trend in real salaries may affect which members of the bar are willing to join the federal bench. Table 5 shows that the net assets of district and circuit court judges alike are generally increasing, not just in the aggregate but across different sectors of the legal profession from which these judges come. This conclusion supports Chief Justice Rehnquist's claims that inadequate salaries will have adverse selection effects, namely that the job will disproportionately attract members of the bar already possessing wealth. ${ }^{84}$ Independently wealthy judges will be less cost-sensitive to stagnant or declining salaries and therefore less inclined to retire early. This leads to a judiciary that is less representative of society.

Second, this outcome may be explained by considering judges' overall compensation, which extends beyond their salary. Putting aside whatever psychological benefit judges derive from their job, judges receive additional nonsalary benefits. Each active judge, whether on a district or circuit court, receives secretarial support and at least two full-time law clerks. The number of clerks allotted to judges has grown over time, in large part in response to their burgeoning caseloads. These clerks work long hours and provide assistance to judges, ranging from research to drafting opinions as well as additional duties in district court chambers. ${ }^{85}$ While the judge is always ultimately responsible for the work product that leaves his or her chambers, the increased clerk support helps reduce the amount of work for the judge.

There is also the trade-off between leisure and labor time that still works in favor of federal judges. While there is no disputing that federal judges, by and large, work very hard, they have much greater autonomy and discretion than their counterparts in private practice. Judges do not report to a superior or client, they enjoy lifetime tenure, and their only dayto-day constraints are self-imposed.

In addition to law clerks, federal judges receive other perquisites. Provided they remain on the bench long enough to qualify for their pension under the "Rule of $80,{ }^{, 86}$ federal judges can retire at full salary, effective at

83. See Charles M. Tiebout, $A$ Pure Theory of Local Expenditures, 64 J. PoL. Econ. 416, 418-19 (1956) (proposing that individual consumers may express their dissatisfaction for a good, such as a locality, by leaving).

84. See Time of Crisis, supra note 1 (statement of Chief Justice Rehnquist). Specifically, Chief Justice Rehnquist stated, "Our judges will not continue to represent the diverse face of America if only the well to do or the mediocre are willing to become judges." Id.

85. See PoSNER, supra note 11 , at 158 (describing the numerous support functions that law clerks provide for federal judges).

86. The requirements for qualifying for pension have been modified slightly over time. The current standard is what is commonly referred to as the "Rule of 80 ," which requires that the retiring 
the time of retirement. For example, if a district judge retires in 2001 after qualifying for a pension, he or she is entitlcd to receive $\$ 145,100$ annually for the remainder of his or her life. Whereas many jobs offer front-loaded compensation that declines over time, particularly after retirement, judicial compensation is evenly distributed over time, making it a valuable form of compensation, albeit one contingent on long-term commitment. And, unlike pension plans for many members of the workforce, federal judges are not required to draw from their annual salary to contribute to their pension. Further, federal judges receive large private offices ${ }^{87}$ and are fully reimbursed for their expenses when they travel on judicial business. ${ }^{88}$ Of course, it is impossible to know with any precision the aggregate value of in-kind benefits the federal government provides to federal judges, and that amount varies by individual judge. Nonetheless, Figure 7 provides a stark graphical depiction.

judge be at least sixty-five years of age, with age and total years of service on the bench totaling at least eighty years. 28 U.S.C. $\$ 371$ (c) (2002). Prior to 1985, judges were required to be at least sixty-five years of age and to have served on the bench fifteen years. Prior to 1954, judges were required to serve on the bench until they were at least seventy years old, with ten years of service. 28 U.S.C. $\$ 371$ (b) (1952). See also POSNER, supra note 11, at 33.

87. Circuit judges in particular are often given multiple sets of offices, one for their main chambers, and another for when they travel to another city to hear oral argument.

88. This includes instances where district court judges sit on a panel within their circuit, or appellate judges from a particular circuit sit on a panel of another circuit; such forms of compensation are nontaxable. Also, while the Ethics Reform Act of 1989 bars honoraria and limits what outside income judges may earn, judges may accept invitations to judge law school moot court competitions and attend conferences and other gatherings, for which their expenses are covered. See Pub. L. No. 101-94, 103 Stat. 1716 (1989). 
Figure 7

GroWTH IN EXPENDITURES

Judicial Salaries vs. Federal Judiciary Budget, 1962-2001

(UNADJUSTEd Dollars)

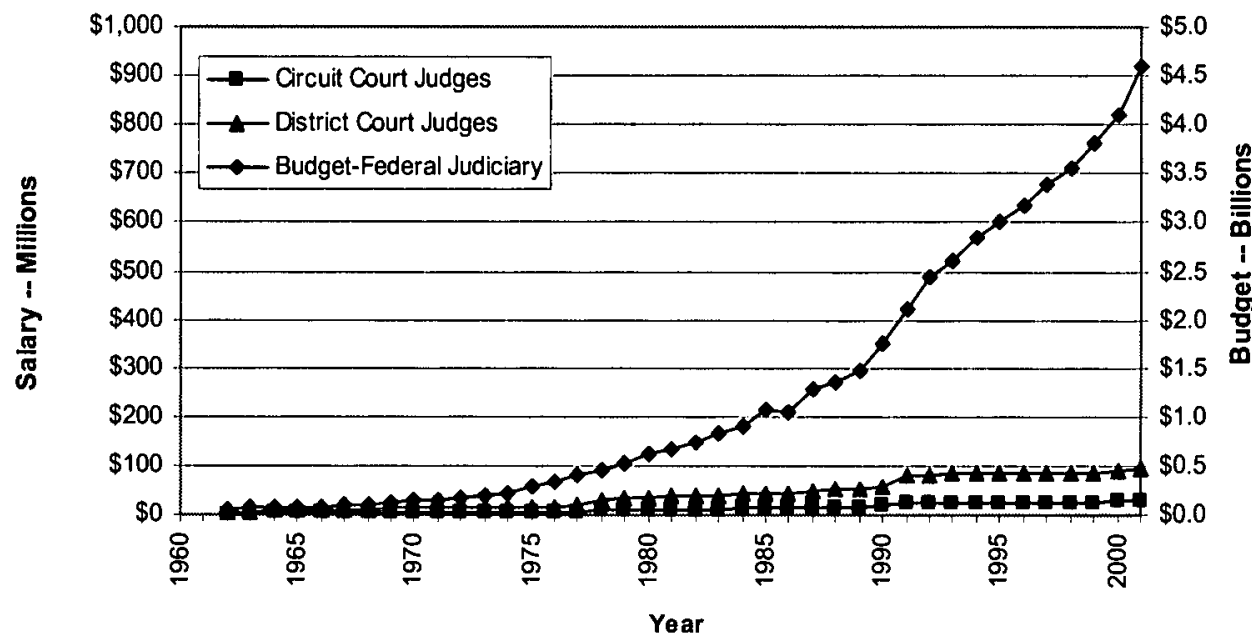

Note: Data provided by the Administrative Office of the U.S. Courts and the Office of Management and Budget. The left-side $y$-axis corresponds to aggregate judicial salaries for active federal judges; the right-side $y$-axis corresponds to the total federal judiciary budget.

Over the past forty years, the total budget for salaries for active federal judges-district and circuit-grew approximately by a factor of fourteen. ${ }^{89}$ The budget for the federal judiciary, over that same period, has grown by a factor of nearly 100: The federal government spent $\$ 50$ million in 1962 on the federal judiciary; in 2001 it spent $\$ 4.6$ billion. To place the growth of judicial salaries and the overall budget in perspective, the historic rate of inflation has been roughly 3\%, meaning that $\$ 100$ in 1962 is now worth about $\$ 600$ in 2002 figures, ${ }^{90}$ reflecting a growth factor of six. Due to the increase in the number of authorized judgeships between 1960 and 2000, aggregate judicial salaries outpaced the historic rate of inflation. On an individual level, however, judicial salarics have essentially kept pace with the historic rate of inflation. ${ }^{91}$

89. This increase was largely driven by the increase in the number of authorized judgeships: individual federal judicial salaries over this same period grew by a factor of roughly only six (below $\$ 25,000$ in 1962 to roughly $\$ 150,000$ in 2001 ).

90. This figure is based on the Consumer Price Index ("CPl"), provided by the Bureau of Labor Statistics. Bureau of Labor Statistics, U.S. Dep't of Labor, Consumer Price IndeX 1913-2002, at ftp://tp.bls.gov/pub/special.requests/cpi/cpiai.txt (last visited Mar. 10, 2003).

91. Circuit court judges earned $\$ 25,500$ in 1962 and $\$ 153,900$ in 2001; district court judges earned $\$ 22,500$ in 1962 and $\$ 145,100$ in 2001. See Judiciary Act of 1789 and subsequent acts; see also POSNER, supra note 11 , at 389 . 
Some of the federal judiciary budget growth can be explained by increases in the number of judges: the number of Article III judges grew from 365 in 1962 to 851 in 2002, ${ }^{92}$ with a corresponding expansion in nonArticle III judges over this time (for example, magistrate, bankruptcy, and tax judges). ${ }^{93}$ Nevertheless, the growth rate in the number of judges cannot fully account for the corresponding growth in the federal judiciary budget. Overhead expenses have increased over this period, due to additional or growing compensation for law clerks and support staff, among other expenses. ${ }^{94}$ Because the federal government does not provide a consistent detailed breakdown of its judiciary budget, ${ }^{95}$ it is impossible to know exactly how these funds are allocated. Still, the annual tables reveal that, at least for the period 1960-2001, the authorized budget for federal district and circuit judges' salaries (in unadjusted dollars) grew by a factor of roughly six per judge, while the authorized budget for support personnel, travel, and miscellaneous expenses grew by a factor of ten..$^{96}$ Although subsequent annual tables combine the aforementioned categories into a single figure, one may speculate that a nontrivial, and possibly growing, portion of the budget goes to provide nonsalary benefits to federal judges, as discussed above.

\section{CONCLUSION}

What do these findings say about the state of the federal judiciary? First, it is important to recognize that the absence of a causal relationship between declining judicial salaries and judicial tenure does not negate the Chief Justice's call for increasing the salaries of federal judges. If we believe that federal judges are underpaid as a matter of substantive fairness, ${ }^{97}$ then the justification for increasing their salaries stands independent of our

92. Fed. Judicial CTr., Courts of the Federal Judiciary, at http://air.fjc.gov/history/dc_frm.html (last visited Feb. 10, 2003).

93. For example, the number of full-time magistrate judges has grown by almost a factor of five over the past thirty years (103 in the spring of 1973 to 471 in the fall of 2001). See ADMIN. OFFICE OF the U.S. CTs., Judicial Business of the United States Courts (2001); Admin. Office of the U.S. Cts., Judicial Business of the United States Courts (1996); Admin. Office of the U.S. Cts., Judicial Business of the United States Courts (1992).

94. The federal judiciary budget does not include the expenses for U.S. Marshalls, who, among other tasks, provide security for judges and staff.

95. While the Administrative Office of the United States Courts records budgetary statistics for the federal judiciary in its directors' annual reports, the means by which it records this information has varied over time, thereby preventing any systcmatic longitudinal analysis.

96. For information for 1960-81, see the Administrative Office of the United States Courts, Annotated Report of the Director for those respective years.

97. In his testimony before the Volcker Commission, Justice Breyer displayed a graph showing that salaries of federal chief judges in the United States, when compared with their counterparts in Canada and England, had - by far-the lowest increase in salary over the past eight years, even though the increase in the cost of living in the United States was greater than or equal to that of the other countries. See Time of Crisis, supra note 1. 
observing shorter tenure rates for judges. And even if we were unpersuaded by the call for higher judicial salaries on principle, we might still reach the same conclusion as a matter of policy. Judges' average net assets (in constant dollars) are continuing to climb, potentially reflecting a financial barrier to the position. This increase suggests that, in the aggregate, opportunity costs for prospective nominees have grown, especially given the significantly higher salaries offered in private practice. If we believe that judicial diversity-economic as well as gender and ethnic-is important, then higher judicial salaries may be in order.

Second, these findings call for further analysis of labor tronds in the federal judiciary. Political scientists and sociologists have long recognized that individuals in any type of bureaucracy rcspond to changes in their compensation and work environment in various ways. Some responses are readily observable, such as exiting the profession. However, as this Article demonstrates, federal judges are not leaving their positions at higher rates than their predecessors. Other responses to bureaucratic change are more subtle, such as changes in effort, increased delegation of duties, and expenditures of resources. ${ }^{98}$ The findings in this Article suggest that these lines of research would be fruitful. 